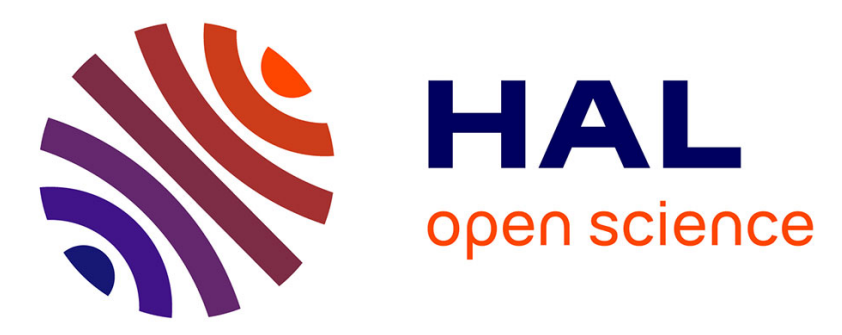

\title{
Adenovirus-mediated fibroblast growth factor 1 expression in the lung induces epithelial cell proliferation: consequences to hyperoxic lung injury in rats.
}

Vanessa Louzier, William Raoul, Aude Leroux, Didier Branellec, Jean-Michel Caillaud, Hélène Many, Micheline Levame, Christophe Delclaux, Serge Adnot, Bernard Maitre

\section{- To cite this version:}

Vanessa Louzier, William Raoul, Aude Leroux, Didier Branellec, Jean-Michel Caillaud, et al.. Adenovirus-mediated fibroblast growth factor 1 expression in the lung induces epithelial cell proliferation: consequences to hyperoxic lung injury in rats.. Human Gene Therapy, 2004, 15 (8), pp.793-804. 10.1089/1043034041648390 . inserm-00990784

\section{HAL Id: inserm-00990784 https://www.hal.inserm.fr/inserm-00990784}

Submitted on 14 May 2014

HAL is a multi-disciplinary open access archive for the deposit and dissemination of scientific research documents, whether they are published or not. The documents may come from teaching and research institutions in France or abroad, or from public or private research centers.
L'archive ouverte pluridisciplinaire HAL, est destinée au dépôt et à la diffusion de documents scientifiques de niveau recherche, publiés ou non, émanant des établissements d'enseignement et de recherche français ou étrangers, des laboratoires publics ou privés. 


\title{
Adenovirus-Mediated Fibroblast Growth Factor 1 Expression in the Lung Induces Epithelial Cell Proliferation: Consequences to Hyperoxic Lung Injury in Rats
}

\author{
VANESSA LOUZIER,,${ }^{1, *}$ WILLIAM RAOUL,${ }^{1, *}$ AUDE LEROUX,${ }^{2}$ DIDIER BRANELLEC, ${ }^{2}$ \\ JEAN-MICHEL CAILLAUD, ${ }^{2}$ HÉLÈNE MANY, ${ }^{1}$ MICHELINE LEVAME, ${ }^{1}$ CHRISTOPHE DELCLAUX, ${ }^{1}$ \\ SERGE ADNOT, ${ }^{1}$ and BERNARD MAITRE ${ }^{1}$
}

\begin{abstract}
High concentrations of oxygen can induce pulmonary toxicity and cause injury to alveolar epithelial and endothelial cells. The present study was performed to determine whether the potent epithelial and endothelial fibroblast growth factor 1 (FGF-1) protected against hyperoxia-induced lung injury. Recombinant adenovirus carrying the gene encoding human secreted FGF-1 (Ad.FGF1) increased the proliferation of lung epithelial cells in vitro. Ad.FGF1 or control vector with an empty expression cassette (Ad.V152) was administered intratracheally to Wistar rats. With Ad.FGF1 $\left(10^{9}, 5 \times 10^{9}, 10^{10}\right.$, or $5 \times 10^{10}$ viral particles [VP]), FGF-1 protein was found in bronchoalveolar lavage fluid 4 days postinfection at levels proportional to the viral dose and was detected in plasma after doses of $10^{10} \mathrm{VP}$ or more were administered. Histological examination of the lungs showed intense proliferation and apoptosis of alveolar and bronchial epithelial cells, with few inflammatory cells. The alveolar architecture returned to normal within 17 days. Rats pretreated with Ad.FGF1 $\left(10^{9}\right.$ or $5 \times 10^{9}$ VP) 2 days before exposure to hyperoxia $\left(95 \% \mathrm{O}_{2}\right)$ survived, whereas rats pretreated with Ad.V152 died within 3 days. In conclusion, adenovirus-mediated FGF-1 overexpression in the lungs causes epithelial cell proliferation and has beneficial effects in hyperoxic lung injury.
\end{abstract}

\section{OVERVIEW SUMMARY}

To test the effect of fibroblast growth factor 1 (FGF-1) overexpression on lung repair after hyperoxia-induced injury, recombinant adenovirus encoding the human secreted FGF1 gene (Ad.FGF1) or control vector containing no gene (Ad.V152) was administered intratracheally to Wistar rats. With Ad.FGF1 (10 ${ }^{9}$ to $5 \times 10^{10}$ viral particles [VP]), FGF-1 protein was found in bronchoalveolar lavage fluid 4 days postinfection at levels proportional to the viral dose. Histology showed proliferation and apoptosis of alveolar and bronchial epithelial cells, which were marked 4 days postinjection, without major inflammatory cell infiltration. Alveolar architecture returned to normal within 17 days. Rats pretreated with Ad.FGF1 $\left(10^{9}\right.$ or $\left.5 \times 10^{9} \mathrm{VP}\right) 2$ days before hyperoxia exposure $\left(95 \% \mathrm{O}_{2}\right)$ survived, whereas controls died within 3 days. In conclusion, adenovirus-mediated FGF-1 lung overexpression causes epithelial cell proliferation and has beneficial effects in hyperoxic lung injury.

\section{INTRODUCTION}

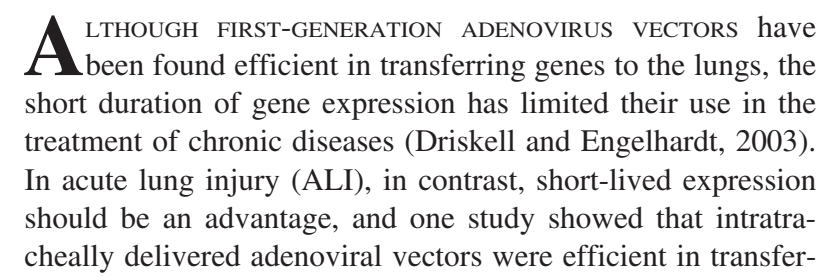

${ }^{1}$ Physiology Department, National Institute for Health and Medical Research (INSERM) Unit 492, Henri Mondor Teaching Hospital, AP-HP, 94010 Créteil, France.

${ }^{2}$ Cardiovascular Gene Therapy Department, Gencell, Vitry sur Seine, France.

*V.L. and W.R. contributed equally to this work. 
ring genes to severely injured, edematous lung tissue (Factor et al., 2002). Epithelial and endothelial proliferation may be critical to recovery from ALI, and the role of several growth factors in lung inflammation and repair has been extensively investigated. Transferring protective growth factors to the alveolar epithelium improves ALI in experimental models, but the potential effects of adenovirus-mediated transfer of growth factor genes in ALI have not been evaluated (Panos et al., 1995; Barazzone et al., 1999). Among growth factor families, fibroblast growth factors (FGFs) are expressed in specific spatial and temporal patterns and are involved in developmental and repair processes. FGF-1 has been isolated from a variety of tissues (Burgess et al., 1986), including adult rat lung, where it is found in the epithelial and interstitial cells of the alveolar septa, ciliated airway cells, nonciliated bronchiolar cells, smooth muscle cells, and type II pneumocytes (Sannes et al., 1992). In addition to being an angiogenic factor that stimulates the growth of endothelial cells, FGF-1 is mitogenic for a wide range of cell types including fibroblasts, smooth muscle cells, and epithelial cells. FGF-1 binds with high affinity to FGF receptors (FGFRs) 1 through 4 but does not seem to bind to FGFR-5 (Kim et al., 2001; Sleeman et al., 2001). Among FGFs, FGF-1 is the most potent mitogen in vitro, irrespective of the FGF receptor it activates. Moreover, FGF-1, together with other FGFs including FGF2 and keratinocyte growth factor (KGF; FGF-7), stimulates DNA synthesis in type II pneumocytes in vitro and in vivo (Leslie et al., 1985, 1990, 1997; Panos et al., 1993; Ulich et al., 1994).

FGF-1 overexpression may promote alveolar repair after ALI via its potent mitogenic effect on several cell types and its ability to stimulate the growth of both epithelial cells and microvascular endothelial cells. We therefore studied the effects of FGF-1 overexpression achieved by adenovirus-mediated gene transfer in a rat model of hyperoxic ALI with predominant damage to alveolar type I and endothelial cells.

\section{MATERIALS AND METHODS}

\section{Construction and production of adenoviral vectors}

A gene for human secreted FGF-1 (signal peptide FGF-1, sp-FGF-1) was engineered by fusion of the human fibroblast interferon signal peptide (FINsp) and the $\alpha$-endothelial cell growth factor open reading frame (Jouanneau et al., 1991). The open reading frame was cloned under the control of the cytomegalovirus (CMV) promoter (positions -522 to +72 ) fused to the thymidine kinase $5^{\prime}$ untranslated region (UTR) (positions +51 to +101$)$ and the simian virus 40 (SV40) late poly(A) signal with no intron (Fig. 1). This expression cassette was inserted into the E1 region of human adenovirus serotype 5 (Ad5) by recombination in Escherichia coli, as described in Crouzet et al. (1997). It is designated Ad.FGF1 in this article. We used the same method to construct the control virus (Ad.V152), which contained the CMV promoter and poly(A) sequences but no transgene. Adenoviruses were produced in the supernatant of 293 cells and then concentrated by tangential flow filtration (J.-M. Guillaume [Gencell, Vitry sur Seine, France], personal communication). Purification and viral titer determination (in viral particles [VP] per milliliter) were performed by high-performance liquid chromatography (Blanche et al., 2000). All viral stocks were subjected to restriction analysis to check the integrity of the virus. The ratio of VPs to plaque-forming units (PFU) was determined and found to be less than 1:100 for each virus. All viral stocks were tested for replication of competent adenoviruses and found to contain fewer than one replicationcompetent adenovirus per $10^{10} \mathrm{VP}$.

\section{$1 \mathrm{HAEO}^{-}$cell culture and proliferation studies}

The $1 \mathrm{HAEo}^{-}$line is derived from human tracheal epithelial cells transfected with mutated SV40 T-antigen and has been extensively described (Cozens et al., 1992). 1 $\mathrm{HAEo}^{-}$bronchial cells were grown in Dulbecco's modified Eagle's medium sup-

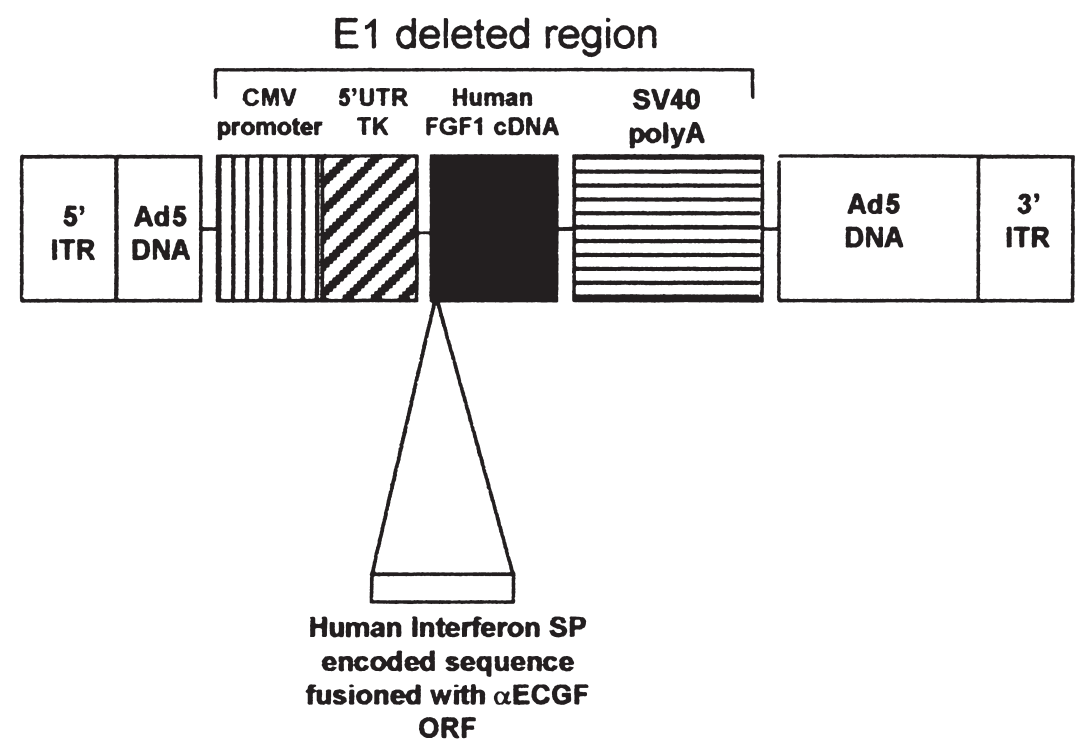

FIG. 1. Diagram representing the expression cassette inserted into the $\mathrm{E} 1$ region of the human Ad5 serotype. a-ECGF, acidic epithelial cell growth factor; CMV, cytomegalovirus; FGF-1, fibroblast growth factor type 1; ITR, inverted terminal repeat; ORF, open reading frame; SP, signal peptide; SV40, simian virus 40; TK, thymidine kinase; UTR, untranslated region. 
plemented with serum substitute Ultroser G (2\%; GIBCO-BRL, Gaithersburg, MD) on a collagen $\mathrm{G}$ (I+III) coating. Cells were grown to $80 \%$ confluence and incubated for $48 \mathrm{hr}$ in fresh serum-free medium containing recombinant FGF-1 at various concentrations (10-200 ng/ml). For adenovirus infection, cells were incubated with Ad.FGF1 or Ad.V152 (1-100 multiplicities of infection [MOIs]) for $1 \mathrm{hr}$ at $37^{\circ} \mathrm{C}$, washed twice with new medium, and incubated for $47 \mathrm{hr}$ in fresh serum-free medium. Cell counts were determined after $48 \mathrm{hr}$ by harvesting cells in trypsin-EDTA and counting them in triplicate with a hemocytometer.

\section{Animal experiments and delivery of adenovirus vectors to the lungs}

Wistar rats (200-250 g body weight) were used for all studies. Animal care and procedures were in accordance with institutional guidelines. Ad.FGF1, or Ad.V152 as the control, was diluted before use in sterile saline, $\mathrm{pH} 7.4$, in a final volume of $150 \mu \mathrm{l}$. The rats were anesthetized with intraperitoneal ketamine $(7 \mathrm{mg} / 100 \mathrm{~g})$ and xylazine $(1 \mathrm{mg} / 100 \mathrm{~g})$. Viral infection of the lungs was achieved by intratracheal instillation of diluted Ad.FGF1 or Ad.V152 (150 $\mu \mathrm{l} / \mathrm{rat})$.

After an intraperitoneal injection of pentobarbital (60 $\mathrm{mg} / \mathrm{kg}$ ), blood samples were drawn from the abdominal aorta. The plasma was separated after centrifugation of the clotted blood samples at $2000 \mathrm{rpm}$ for $10 \mathrm{~min}$ and then stored at $-20^{\circ} \mathrm{C}$. For bronchoalveolar lavage (BAL), a median sternotomy was performed, the trachea was dissected free from the underlying soft tissues, and a $0.6-\mathrm{mm}$ tube was inserted through a small incision in the trachea. BAL was performed by instilling $10 \mathrm{ml}$ of $9 \%$ o $\mathrm{NaCl}$ (one 5-ml and two $2.5-\mathrm{ml}$ aliquots) in situ into the left lung and then recovering the fluid by gentle aspiration. The fluid was centrifuged at $300 \times$ $g$ for $7 \mathrm{~min}$ at $4^{\circ} \mathrm{C}$. The cell-free BAL fluid was stored at $-70^{\circ} \mathrm{C}$ until used for enzyme-linked immunosorbent assay (ELISA).

Immediately after BAL, the lungs were removed and the left lung was fixed by infusing neutral buffered formaldehyde into the trachea. After routine processing and paraffin embedding, multiple sections from each lobe were stained with hematoxylin and eosin.

For transmission electron microscopy, the lungs were fixed in situ by inflation with $10 \mathrm{ml}$ of $2.5 \%$ glutaraldehyde in 0.045

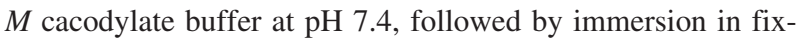
ative. Sections cut from blocks of tissue were examined under an EM 301 microscope (Philips, Eindhoven, The Netherlands).

\section{Evaluation of gene transfer}

FGF-1 protein detection in serum and bronchoalveolar lavage fluid. To evaluate the efficiency of gene transfer, serum and BAL levels of FGF-1 protein were measured in normoxic rats 4,10 , and 17 days after infection with various doses of Ad.FGF1 $\left(10^{9}\right.$ to $\left.5 \times 10^{10} \mathrm{VP}\right)$ or Ad.V152 $\left(10^{10} \mathrm{VP}\right)$ and in hyperoxic rats 4 days after infection with Ad.FGF1 $\left(5 \times 10^{9}\right.$ VP) or Ad.V152 $\left(5 \times 10^{9} \mathrm{VP}\right)$.

The ELISA kit used in this study was developed for Aventis (Strasbourg, France) by the custom development service of R\&D Systems (Minneapolis, MN). The kit recognizes naturally occurring FGF-1 from both humans and rats.
Immunohistochemistry of FGF-1. To determine which cells were transduced with Ad.FGF1, we performed an immunochemistry study of lung sections in normoxic rats 4 days after Ad.FGF1 $\left(5 \times 10^{9} \mathrm{VP}\right)$ or Ad.V152 $\left(5 \times 10^{9} \mathrm{VP}\right)$ administration. Paraffin sections were dewaxed by passage through xylene and graded alcohols. Endogenous peroxidase activity was then blocked with $0.6 \%$ hydrogen peroxide in methanol, and nonspecific binding sites were blocked with normal goat serum. The slides were incubated overnight at $4{ }^{\circ} \mathrm{C}$ with a polyclonal rabbit antibody against human FGF-1 (R\&D Systems Europe, Abingdon, UK). The samples were then incubated for $30 \mathrm{~min}$ with a biotinylated goat anti-rabbit antibody and with avidinbiotin complex (DakoCytomation, Carpinteria, CA). Visualization was obtained after a few minutes of incubation with diaminobenzidine (DAB) as the chromatogen. Immunohistochemical controls also included slides of lungs from Ad.FGF1treated rats incubated with normal dilute rabbit serum instead of the first antibody.

\section{Evaluation of the inflammatory effects of Ad.FGFI}

Cytological evaluation. For cytological evaluation of inflammation, BAL pellets were resuspended with the remaining supernatants and the cells were counted. Cytospin preparations were made by placing $0.2 \mathrm{ml}$ (BAL aliquots) in each funnel of a Cytospin III (Shandon, Cergy-Pontoise, France). The cells were fixed and stained with Diff-Quick (Dade Behring, La Défense, France), and a differential leukocyte count was performed.

Histological evaluation. For histological evaluation, light microscopy was performed on samples from normoxic rats 4 days after administration of various doses of Ad.FGF1 $\left(10^{9}\right.$, $5 \times 10^{9}, 10^{10}$, or $\left.5 \times 10^{10} \mathrm{VP}\right)$ or Ad.V152 $\left(10^{9}\right.$ to $5 \times 10^{10}$ $\mathrm{VP})$ and 10 and 17 days after administration of $10^{9}, 5 \times 10^{9}$, or $10^{10} \mathrm{VP}$. In hyperoxic rats, histological sections were also examined at various times after infection with Ad.FGF1 or Ad.V152 $\left(10^{9}\right.$ or $\left.5 \times 10^{9} \mathrm{VP}\right)$. The inflammatory response was assessed on the basis of an empiric semiquantitative scale, as described previously (Brody et al., 1994).

Determination of lung wet-to-dry weight ratio. The medial lobe of the right lung was excised, dissected, immediately weighed, and then placed in a desiccating oven at $65^{\circ} \mathrm{C}$ for 72 $\mathrm{hr}$, at which point the dry weight was measured. The wet-todry weight ratio was used to quantify lung water content (Staub, 1974). Hemoglobin concentration was measured in ultracentrifuged $(14,000 \times g$ for $10 \mathrm{~min})$ lung homogenate.

\section{Effect of Ad.FGF1 administration on animal survival}

Two days after intratracheal Ad.FGF1 $\left(10^{9}, 5 \times 10^{9} \mathrm{VP}\right)$ or Ad.V152 $\left(10^{9}, 5 \times 10^{9} \mathrm{VP}\right)$ administration, the rats were exposed to $95 \%$ oxygen in a Plexiglas hyperoxia chamber. The flow of gas was kept constant at 8 liters/min. The inspired fraction of oxygen was checked with a gas analyzer at the end of each experiment. The rats had free access to food and water and were housed at room temperature. In a first experiment, the rats ( $n=6-11$ per group) were killed $48 \mathrm{hr}$ after exposure to hyperoxia and used to evaluate pulmonary gene transfer, histology, edema, and apoptosis. In a second experiment, eight rats 
per group were exposed to hyperoxia and their survival was evaluated.

\section{Evaluation of lung apoptosis and proliferation after Ad.FGF1 administration}

Proliferating cell nuclear antigen labeling. A PCNA (proliferating cell nuclear antigen) staining kit (Zymed, South San Francisco, CA) was used. The kit uses a biotinylated PCNA mouse monoclonal antibody (clone PC 10) that eliminates the need for a species-specific secondary antibody. Immunolocalization was performed on paraffin-embedded formalin-fixed rat lungs. Briefly, after paraffin removal in xylene, the sections were rehydrated and exposed for 10 min to $\mathrm{H}_{2} \mathrm{O}_{2}(3 \%$ in methanol) to quench endogenous peroxidase. The sections were exposed to PCNA monoclonal antibody for $50 \mathrm{~min}$. To avoid background staining, the primary antibody was diluted (1:5) with bovine serum albumin (1\% in $10 \mathrm{~m} M$ phosphate-buffered saline [PBS]). Immunodetection was then performed with peroxidase-conjugated streptavidin as the signal generator and $\mathrm{DAB}$ as the chromogen to stain PCNA-containing nuclei dark brown. Counterstaining was done with hematoxylin. Negative controls for nonspecific binding were performed by omitting the step with the primary antibody.

Image analysis of PCNA-labeled sections was done with a charge-coupled device Iris camera (CCD Iris; Sony, Tokyo, Japan) coupled with a light microscope (Laborlux; Leica Microsystems, Bensheim, Germany). PCNA staining was estimated with Perfect Image software (ClaraVision, Orsay, France), which discriminates between two colors on the basis of their proportions of red, green, and blue (dark brown nuclei for DAB staining and blue for counterstained areas) with $\pm 10 \%$ variation. From binary images, at least 20 fields per section were analyzed. Results were obtained as the ratio of dark brown staining to blue staining, and expressed as a percentage (DAB nuclear staining relative to total lung parenchyma).

Terminal deoxyribonucleotidyltransferase-mediated dUTP nick end-labeling staining. The terminal deoxyribonucleotidyltransferase (TdT)-mediated dUTP nick end-labeling (TUNEL) method is derived from the method described by Gavrieli et al. (1992), with digoxigenin being substituted for the hapten biotin. We used the ApopDETECT peroxidase kit from Qbiogene (Strasbourg, France). Briefly, after paraffin removal in xylene, the sections were rehydrated and exposed to proteinase $\mathrm{K}$ (Promega, Madison, WI) to improve histological marker penetration. Endogenous peroxidase was quenched with $3 \% \mathrm{H}_{2} \mathrm{O}_{2}$. The enzyme TdT was added to attach UTP-digoxigenin nucleotides to the $3^{\prime}-\mathrm{OH}$ ends of single- or double-stranded DNA (located in apoptotic bodies). The reaction was stopped with specific buffer, and labeled DNA fragments were allowed to bind to an anti-digoxigenin antibody conjugated to a peroxidase reporter molecule. DAB was used to stain nuclei dark brown and hematoxylin was used for counterstaining.

Caspase 3-like activity assay. After isolation, right lungs were homogenized in a buffer containing $50 \mathrm{~m} M$ HEPES, $0.1 \%$ CHAPS, $5 \mathrm{~m} M$ dithiothreitol (DTT), $0.1 \mathrm{~m} M$ EDTA, and $0.1 \%$ Triton X-100, using an Ultra-Turrax homogenizer (IKA Werke,
Staufen, Germany). Lung tissue homogenates were centrifuged at $10,000 \times g$ for $15 \mathrm{~min}$, and supernatants were stored at $-70^{\circ} \mathrm{C}$ until use in the caspase 3 -like activity assay. Direct protein quantitation was done by the Bradford method with $\mathrm{IgG}$ standardization purchased from Bio-Rad (Ivry sur Seine, France). The cytosolic extract was incubated at $37^{\circ} \mathrm{C}$ with a 200 $\mu M$ concentration of the substrate Ac-DEVD-pNA in 96-well microtiter plates (CASPASE-3 cellular activity assay kit PLUS; BIOMOL Research Laboratories, Plymouth Meeting, PA). At various time points, hydrolytic activities were determined by measuring the absorbance of $p$-nitroaniline at $405 \mathrm{~nm}$. Caspase activity was expressed as picomoles per minute per microgram of protein.

\section{Statistical analysis}

All results are reported as means \pm SEM. Two-way analysis of variance (ANOVA) was performed to compare the effect of Ad.FGF1 and Ad.V152 pretreatment in normoxic and hyperoxic animals, followed by the Fisher test to compare Ad.FGF1 and Ad.V152 for each oxygenation condition.

Survival curves (Kaplan-Meier plots, $n=8$ for each group) were compared by log rank test. $p$ Values $<0.05$ were considered statistically significant.

\section{RESULTS}

\section{Effect of Ad.FGF1 gene transfer in vivo and in vitro}

Effect of Ad.FGF1 on epithelial cell proliferation. We first confirmed the growth effect of recombinant FGF-1 on $1 \mathrm{HAEo}^{-}$ cells and determined the efficacy of Ad.FGF1 in vitro. As shown in Fig. 2, Ad.FGF1 induced a dose-dependent increase in $1 \mathrm{HAEO}^{-}$cell counts that was similar in magnitude to that induced by recombinant FGF-1.

Detection of FGF-1 in lung tissue, BAL fluid, and plasma. FGF-1 immunostaining of adult rat lungs 4 days after Ad.FGF1 $\left(5 \times 10^{9} \mathrm{VP}\right)$ administration was localized in bronchiolar (Fig 3B, panel b) and alveolar (Fig. 3B, panel a) epithelial cells, type II epithelial cells, macrophages, and fibroblasts. Immunostained cells were visible throughout the right and left lungs. They were located mainly in the bronchiolar and alveolar areas. Immunostaining occurred only in proliferating areas. There was no immunostaining in lungs from Ad.V152-pretreated controls.

In BAL fluid obtained 4 days after adenovirus administration to normoxic rats, FGF-1 levels increased in a dose-dependent manner up to $10^{10} \mathrm{VP}$ (Fig. 3A). Only small amounts of FGF-1 were detected after Ad.V152 administration, with no differences across doses. After Ad.FGF1 $\left(5 \times 10^{9} \mathrm{VP}\right)$ or Ad.V152 $\left(5 \times 10^{9} \mathrm{VP}\right)$ pretreatment, FGF-1 levels were similar in BAL fluid from hyperoxic and normoxic rats $(5.9 \pm 1.4$ and $1.0 \pm 0.2 \mathrm{ng} / \mathrm{ml}$ BAL fluid versus $5.8 \pm 1.3$ and $1.3 \pm 0.1$ $\mathrm{ng} / \mathrm{ml}$ BAL fluid, respectively) on day 4 . FGF-1 levels on days 10 and 17 were not significantly higher than in the controls (data not shown) in normoxic or hyperoxic rats.

Plasma FGF-1 assays found FGF-1 at levels ranging from 0 to $150 \mathrm{pg} / \mathrm{ml}$ after administration of $10^{10}$ to $5 \times 10^{10} \mathrm{VP}$ of 
FIG. 2. Effects of recombinant FGF-1, Ad.FGF1, and Ad.V152 on the proliferation of human bronchial epithelial cells $\left(1 \mathrm{HAEo}^{-}\right)$. At the end of incubation, cells were harvested and counted with a hemocytometer. Shown are the effects of serum substitute Ultroser G (2\%), FGF-1 (10 to $200 \mathrm{ng} / \mathrm{ml}$ of medium), and Ad.FGF1 or Ad.V152 at the concentrations indicated. Values represent means \pm SEM of six experiments. *Significant difference compared with control values, $p<0.05$.

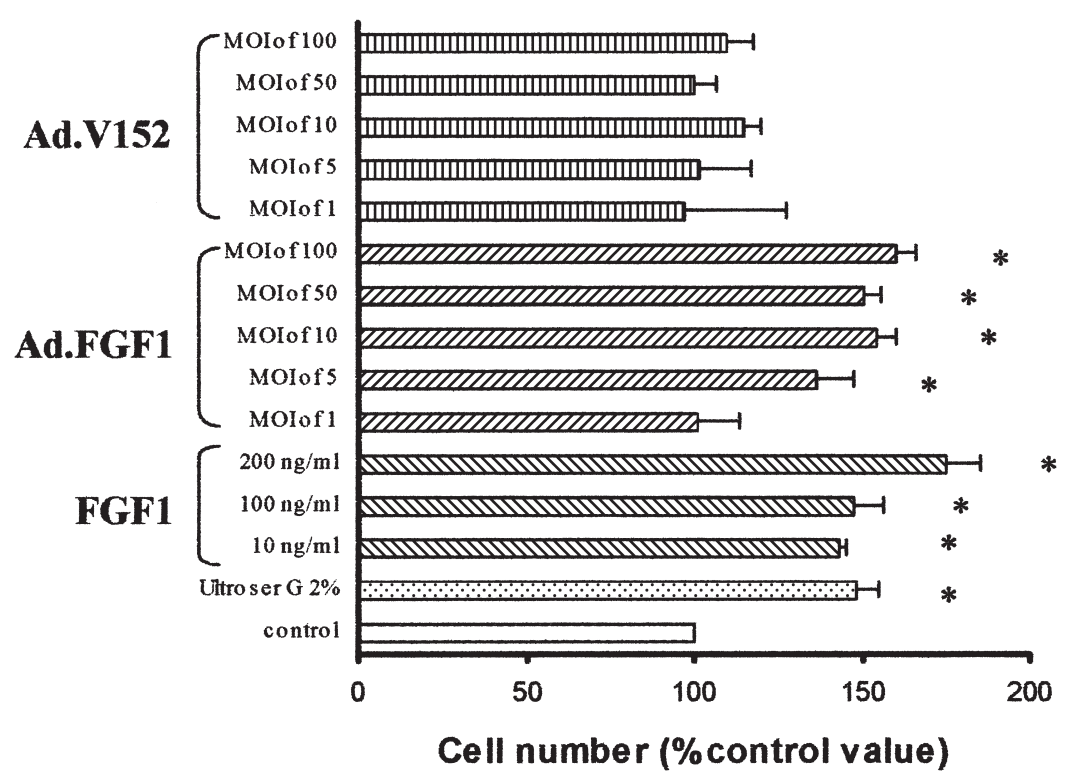

Ad.FGF1. No plasma FGF-1 was detected with lower doses of Ad.FGF1 or with any dose of Ad.V152.

Histological findings after intratracheal adenovirus administration. Sections taken 4 days after administration of $10^{9}, 5 \times$ $10^{9}, 10^{10}$, or $5 \times 10^{10}$ VP of Ad.FGF1 showed intense proliferation of alveolar epithelial cells and bronchial cells located only in the terminal bronchoalveolar areas. This strong effect is illustrated in Fig. 4A, which compares $5 \times 10^{9} \mathrm{VP}$ of Ad.FGF1 and Ad.V152. Alveolar filling and bronchial budding were seen in areas showing intense cell hyperplasia (Fig. 4A, panel a). Bronchiolar hyperplasia was visible as invagination and pseudostratification of the epithelial lining of the small distal bronchi, which normally are lined by a single layer of epithelium (Fig. 4A, panel d). The large airways did not show epithelial hyperplasia. Pulmonary type II epithelial cells were identified by electron microscopy as proliferating cells in hyperplastic alveolar areas (Fig. 5). Mitotic figures were seen in pneumocytes (Fig. 5) of hyperplastic areas, indicating cellular proliferation. These changes occurred in response to each of the Ad.FGF1 doses tested, although the number of areas involved was greatest with the highest doses of Ad.FGF1. However, the major alterations in the alveolar region precluded histological evaluation of the endothelial cells. No epithelial cell hyperplasia or proliferation was visible in the lungs from control rats injected with Ad.V152 (Fig. 4A, panels b, e, and h).

Over time, the histological alterations noted on day 4 resolved gradually. On day 10 , the slides showed persistent thickening of the alveolar septa due to an increase in the number of cells. On day 17, the alveoli seemed almost normal; however, a detailed examination of the septa revealed focal increases in the number of nuclei (Fig. 4A, panel c), bronchial budding (Fig. 4A, panel $\mathrm{f}$ ), and mesenchymal cell proliferation.

In the rats exposed to hyperoxia, the histological findings were similar to those in the normoxic rats 4 days after Ad.FGF1 administration ( 2 days after the beginning of exposure to $95 \%$ $\mathrm{O}_{2}$ ) (Fig. 4B, panels $\mathrm{j}$ and $\mathrm{m}$ ), except for marked inflammation (see below). In the surviving hyperoxic rats 17 days after Ad.FGF1 administration (15 days after the beginning of exposure to $95 \% \mathrm{O}_{2}$ ), cell proliferation was less marked, although the decrease occurred at a slower rate than in the normoxic rats. The histological profile on day 17 in the hyperoxic rats was comparable to that on day 10 in the normoxic rats (Fig. 4B, panels 1 and o).

\section{Lung inflammation after adenovirus administration}

Histological and cytological evaluation of inflammation after gene transfer. First, the location and extent of the inflammatory response were assessed. Both characteristics showed dose-dependent changes after adenovirus administration: 4 days after Ad.FGF1 or Ad.V152 administration at doses of $10^{9}$ to $10^{10} \mathrm{VP}$, no inflammation was detectable by this method, and with doses greater than $5 \times 10^{10} \mathrm{VP}$ only mild inflammation was seen. In the rats exposed to $95 \% \mathrm{O}_{2}$, on day 4 after Ad.FGF1 or Ad.V152 $\left(10^{9}\right.$ and $\left.5 \times 10^{9} \mathrm{VP}\right)$ administration, we found patchy mononuclear and mixed cell infiltrates composed primarily of macrophages and neutrophils, as well as sparse foci of mild damage to alveolar and bronchiolar epithelial cells.

Second, a Cytospin BAL fluid preparation was used to compare BAL cell recruitment after adenovirus administration in normoxic and hyperoxic rats. On day 4 after adenovirus administration, total cell counts were similar under the two oxygenation conditions but were significantly affected by adenovirus administration $(p<0.05)$, with no interaction. In both normoxic and hyperoxic rats, total cell counts were similar after administration of Ad.V152 or Ad.FGF1 at $10^{9}$ VP but were significantly increased after Ad.FGF1 administration at $5 \times 10^{9}$ VP (Table 1). The BAL fluid neutrophil count was significantly 


\section{A}

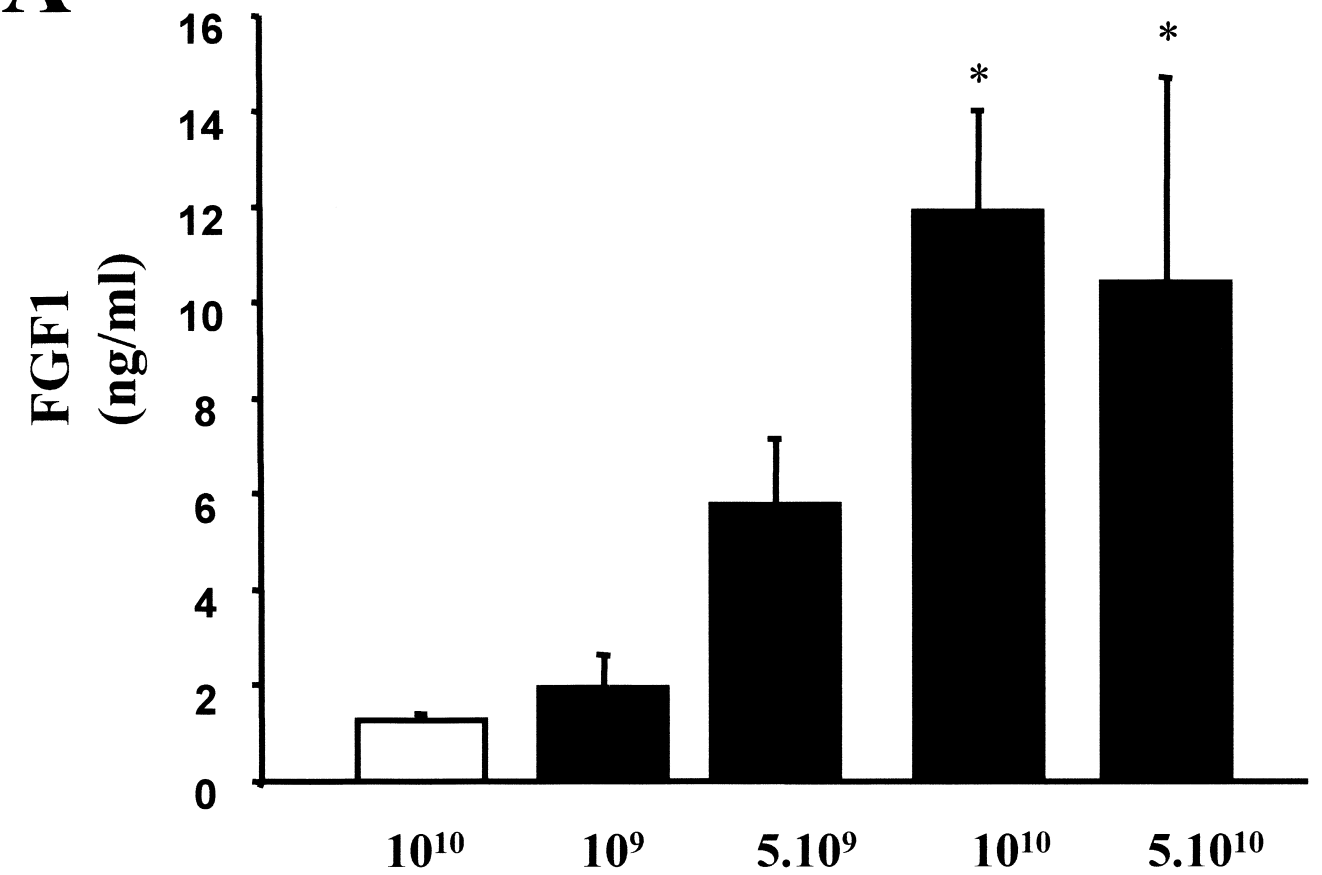

B
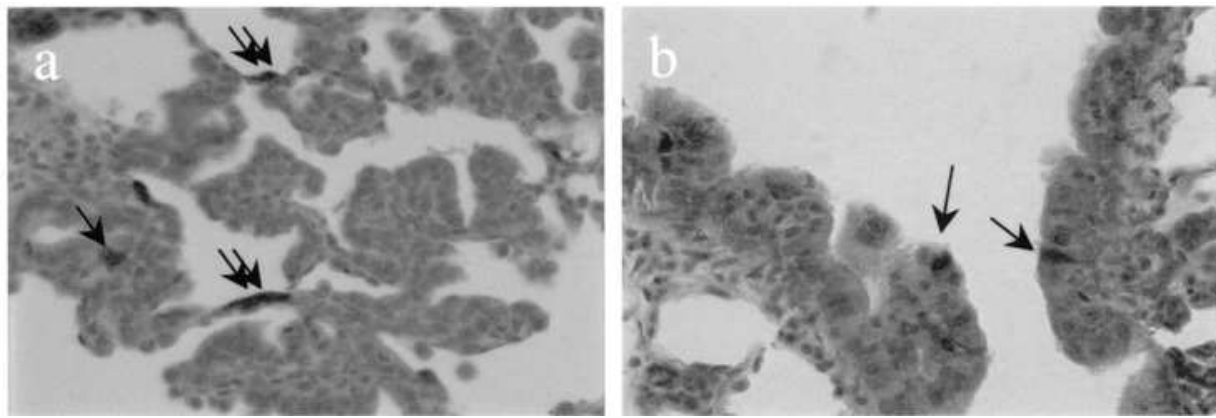

FIG. 3. Evaluation of in vivo gene transfer. (A) FGF-1 levels in bronchoalveolar lavage (BAL) fluid from normoxic rats 4 days after treatment with Ad.V152 (open column) at a dose of $10^{10} \mathrm{VP}(n=5)$ or with Ad.FGF1 (solid columns) at doses of $10^{9}$ VP $(n=5), 5 \times 10^{9} \mathrm{VP}(n=6), 10^{10} \mathrm{VP}(n=5)$, and $5 \times 10^{10} \mathrm{VP}(n=4)$. BAL was performed with saline, and immunoreactive FGF-1 was measured in a final volume of $10 \mathrm{ml}$ for each rat. Values represent means \pm SEM of four to six experiments. *Significant difference compared with Ad.V152 values, $p<0.05$. (B) Light micrograph of adult normoxic rat lung sections stained with anti-FGF-1 antibody 4 days after pretreatment with Ad.FGF1 $\left(5 \times 10^{9} \mathrm{VP}\right)$. (a) Positive staining (brown) of epithelial cells in the alveolar septum (double arrows) and of macrophages (single arrows). Original magnification: $\times 40$. (b) Positive staining (brown) of bronchiolar epithelial cells (single arrows). Original magnification: $\times 40$.

FIG. 4. (A) Histological lung sections of animals treated with adenovirus in normoxia. (a, d, and g) Four days after intratracheal instillation of Ad.FGF1 $\left(5 \times 10^{9} \mathrm{VP}\right)$ in normoxic rats, abnormal hyperplastic areas are visible at the terminal bronchioalveolar junctions (a); higher power views show epithelial hyperplasia with bronchial budding (d) and alveolar filling resulting from typical alveolar epithelial cell hyperplasia (g). (b, e, and h) Four days after intratracheal instillation of the control Ad.V152 $\left(5 \times 10^{9} \mathrm{VP}\right)$ in normoxic rats, the lung architecture is normal and slight inflammation is visible in some alveolar spaces (e). (c, f, and i) On day 17 after intratracheal instillation of Ad.FGF1 $\left(5 \times 10^{9} \mathrm{VP}\right)$ in normoxic rats, the hyperplastic areas are no longer visible but bronchial budding is still present (f) and numerous nuclei of alveolar epithelial cells are seen (f). (B) Histological lung sections of animals treated with adenovirus in hyperoxia. ( $\mathrm{j}$ and $\mathrm{m}$ ) Four days after intratracheal instillation of Ad.FGF1 $\left(5 \times 10^{9} \mathrm{VP}\right)$ and 2 days after $95 \% \mathrm{O}_{2}$ exposure, hyperplastic areas are visible, as well as an inflammatory cell infiltrate. $\left(\mathrm{k}\right.$ and $\mathrm{n}$ ) Four days after intratracheal instillation of Ad.V152 $\left(5 \times 10^{9} \mathrm{VP}\right)$ and 2 days after $95 \% \mathrm{O}_{2}$ in rats, mild damage to alveolar and bronchiolar spaces is visible with areas of edema and inflammatory cell infiltrate. (1 and o) Seventeen days after intratracheal instillation of Ad.FGF1 $\left(5 \times 10^{9} \mathrm{VP}\right)$ in rats exposed to $95 \% \mathrm{O}_{2}$ for 15 days, the hyperplastic areas are decreased, but numerous alveolar epithelial cells are visible, as well as inflammatory cells. Light micrographs; hematoxylin-eosin staining; original magnification: $\times 5$ (A and $\mathbf{B}$, top row), $\times 20$ (A, middle row; $\mathbf{B}$, bottom row), and $\times 40$ (A, bottom row). 


\section{A. NORMOXIA}
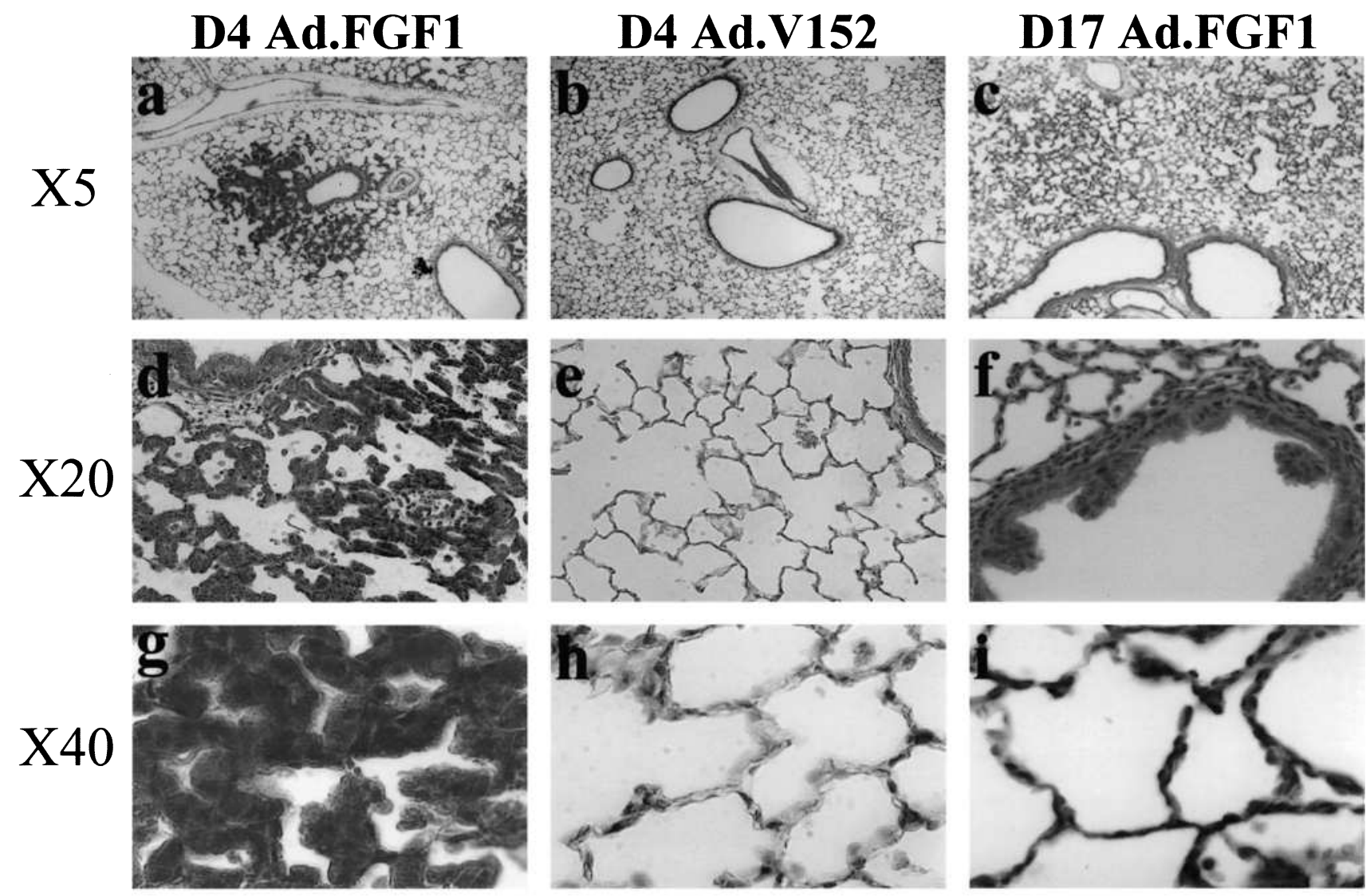

\section{B. HYPEROXIA}
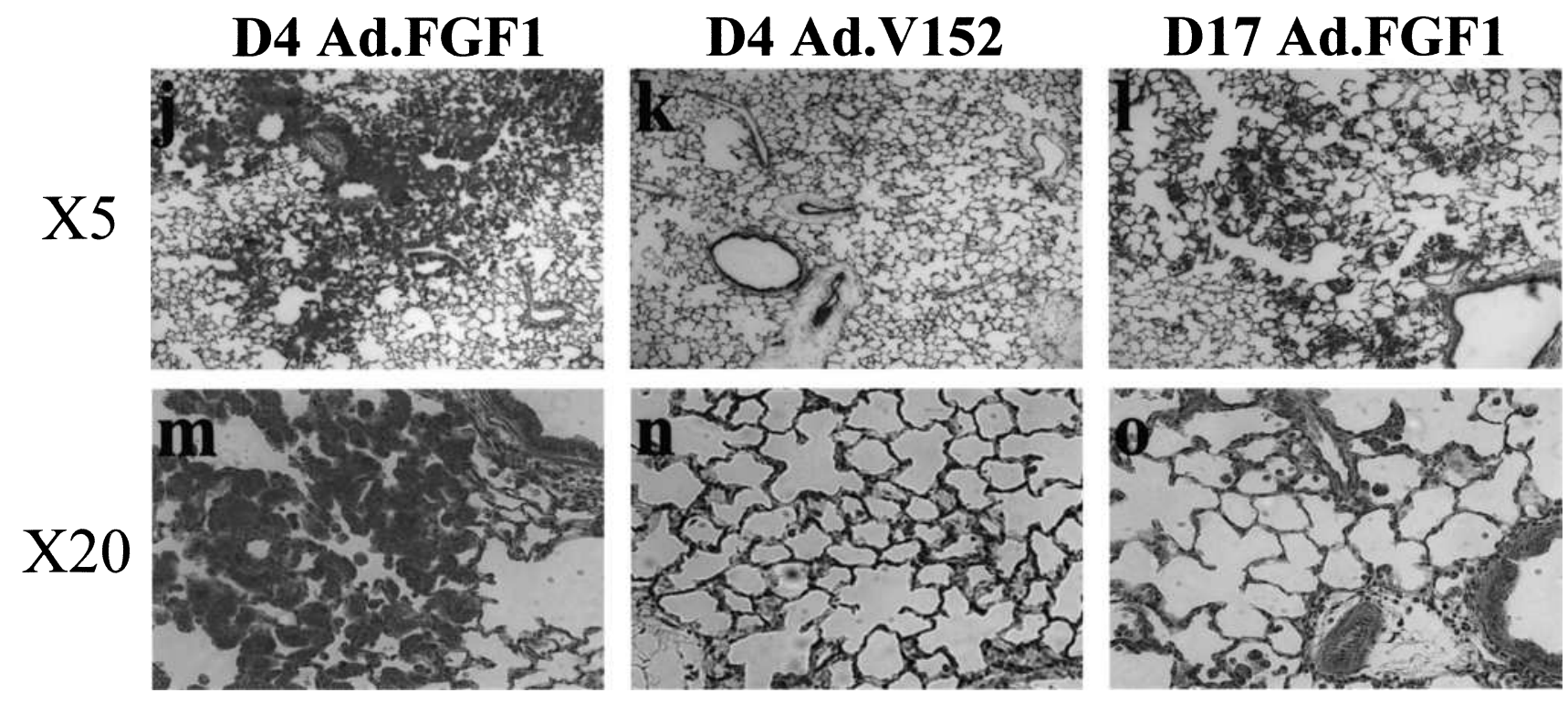

FIG. 4. 

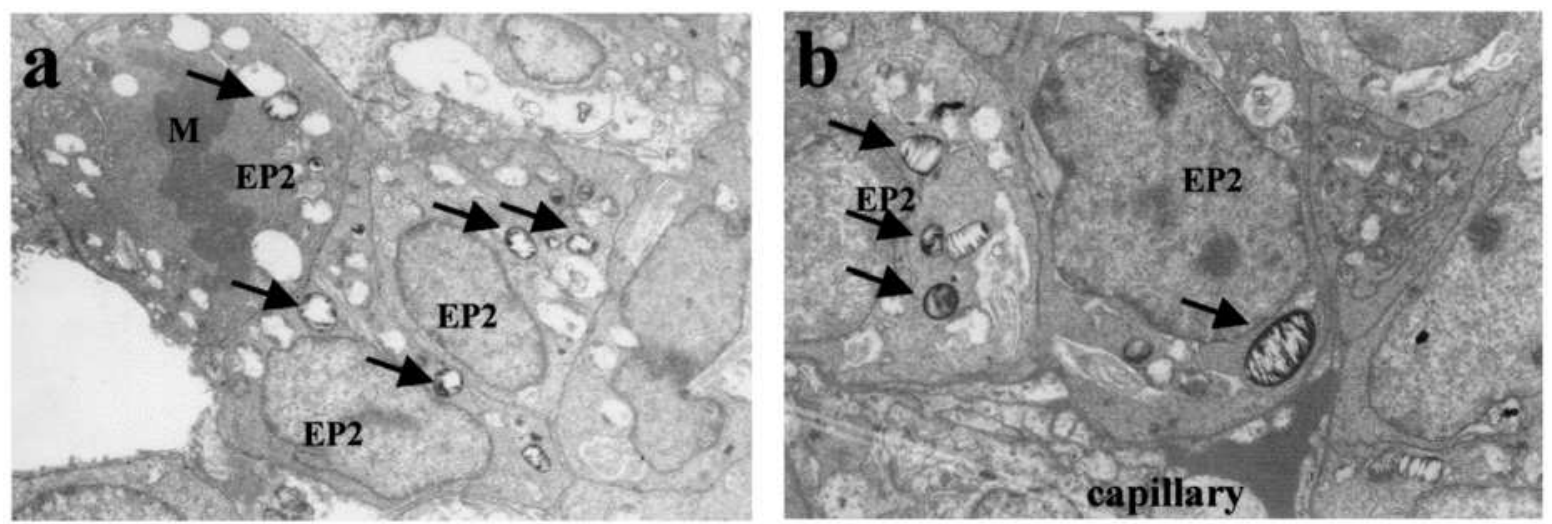

FIG. 5. (a and b) Electron micrographs of areas of alveolar hyperplasia in lungs from normoxic rats 4 days after intratracheal Ad.FGF1 administration $\left(5 \times 10^{9} \mathrm{VP}\right)$ : alveolar type II epithelial cells $(\mathrm{EP} 2)$ containing cytoplasmic lamellar inclusions (arrows) and undergoing division $(\mathrm{M}$, mitosis). Original magnification: (a) $\times 2800$; (b) $\times 3600$.

influenced by the oxygenation condition $(p<0.01)$ and by adenovirus treatment $(p<0.05)$, with no interaction. BAL neutrophil counts were higher after hyperoxia than after normoxia $(p<0.01)$. Ad.FGF1 administration at $5 \times 10^{9}$ VP significantly increased the BAL neutrophil counts in normoxic but not hyperoxic rats, as compared with Ad.V152 or Ad.FGF1 at $10^{9}$ VP $(p<0.05$; see Table 1$)$.

Wet-to-dry lung weight ratio. The respiratory rate was increased in normoxic rats given Ad.FGF1 at $5 \times 10^{9} \mathrm{VP}$. The gross appearance of the heart was normal, whereas the lungs were enlarged and edematous. The wet-to-dry lung weight ratio was increased in rats given Ad.FGF1 at $5 \times 10^{9} \mathrm{VP}$ as compared with Ad.V152 or Ad.FGF1 at $10^{9} \mathrm{VP}(5.36 \pm 0.16,4.7 \pm$ 0.06 , and $4.91 \pm 0.15$, respectively, $n=5-10 ; p<0.05)$ in normoxic but not hyperoxic rats $(5.77 \pm 0.23,5.78 \pm 0.19$, and $5.83 \pm 0.1$, respectively, $n=5-8$ ). To explore the hypothesis that neovascularization responsible for an increase in pul- monary blood volume contributed to increase the wet-to-dry lung weight ratio after Ad.FGF1, we measured the lung hemoglobin content (Saria and Lundberg, 1983) in ultracentrifuged lung homogenates; no increases were found at any time point, ruling out this hypothesis (data not shown).

\section{Effect of Ad.FGF1 on rat survival during hyperoxia}

To determine whether Ad.FGF1 limited $\mathrm{O}_{2}$ toxicity, in rats exposed to $95 \% \mathrm{O}_{2}$ we compared survival between the groups $(n=8)$ pretreated with Ad.FGF1 $\left(10^{9}\right.$ or $\left.5 \times 10^{9} \mathrm{VP}\right)$ versus the groups pretreated with Ad.V152 (10 $0^{9}$ or $\left.5 \times 10^{9} \mathrm{VP}\right)$ (Fig. 6). All the Ad.V152 control rats died within $72 \mathrm{hr}$ of initiation of $95 \% \mathrm{O}_{2}$ exposure. In contrast, the Ad.FGF1-pretreated rats (Fig. 6) survived for at least $70 \mathrm{hr}$ in $95 \% \mathrm{O}_{2}$; more than $60 \%$ of those given the $5 \times 10^{9} \mathrm{VP}$ dose and $50 \%$ of those given $10^{9}$ VP survived 10 days or longer ( $p<0.001$ for Ad.FGF1 versus Ad.V152 with the two adenovirus doses).

Table 1. Inflammatory Cells in Bronchoalveolar Lavage Fluid from Rat lungs 4 Days After Intratracheal Ad.FGF1 Administration ${ }^{\mathrm{a}}$

\begin{tabular}{|c|c|c|c|c|}
\hline Condition & $\begin{array}{l}\text { Parameter } \\
\text { measured }\end{array}$ & $\begin{array}{c}A d . V 152^{\mathrm{b}} \\
\left(10^{9} / 5 \times 10^{9} \mathrm{VP}\right)\end{array}$ & $\begin{array}{c}A d . F G F 1^{\mathrm{c}} \\
\left(10^{9} \mathrm{VP}\right)\end{array}$ & $\begin{array}{c}\text { Ad.FGF } 1^{\mathrm{c}} \\
\left(5 \times 10^{9} V P\right)\end{array}$ \\
\hline \multirow[t]{3}{*}{ Normoxia } & $\begin{array}{l}\text { Total cell count } \\
\quad\left(\times 10^{5} / \mathrm{ml} \text { BAL fluid }\right)\end{array}$ & $1.6 \pm 0.3$ & $1.2 \pm 0.1$ & $2.2 \pm 0.3^{\mathrm{d}}$ \\
\hline & Macrophages $(\%)$ & $96.7 \pm 0.9$ & $88.6 \pm 3.0$ & $72.5 \pm 3.6^{\mathrm{d}}$ \\
\hline & Neutrophils (\%) & $2.8 \pm 0.6$ & $9.4 \pm 2.8$ & $22 \pm 0.5^{\mathrm{d}}$ \\
\hline \multirow[t]{3}{*}{ Hyperoxia } & $\begin{array}{l}\text { Total cell count } \\
\quad\left(\times 10^{5} / \mathrm{ml} \mathrm{BAL} \mathrm{fluid}\right)\end{array}$ & $1.6 \pm 0.3$ & $1.0 \pm 0.3$ & $2.3 \pm 0.5^{\mathrm{d}}$ \\
\hline & Macrophages $(\%)$ & $85.3 \pm 7.4$ & $82.8 \pm 4.0$ & $79.2 \pm 2.8$ \\
\hline & Neutrophils (\%) & $13.5 \pm 6.9$ & $15.5 \pm 4.3$ & $18.8 \pm 2.5$ \\
\hline
\end{tabular}

Abbreviations: BAL, bronchoalveolar lavage; VP, viral particles.

${ }^{a}$ Bronchoalveolar lavage was performed 4 days after intratracheal instillation of adenovirus (Ad.FGF1 or Ad.V152) in animals exposed to normoxia or hyperoxia for 2 days. Ad.V152 vector served as the control. Inflammatory cells in bronchoalveolar lavage fluid were recovered by Cytospin centrifugation and identified by differential staining. Polymorphonuclear neutrophils and macrophages are represented as percentages of total inflammatory cells. Values represent means \pm SEM.

$\mathrm{b}_{n}=11$.

${ }^{\mathrm{c}} n=6$.

${ }^{\mathrm{d}} p<0.05$ compared with Ad.V152 values. 


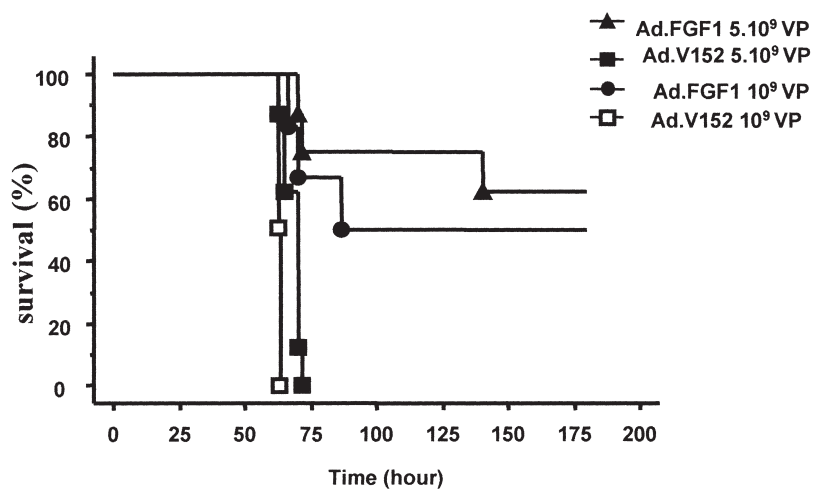

FIG. 6. Survival of adenovirus-pretreated rats exposed to $95 \% \mathrm{O}_{2}$. Rats were pretreated with adenovirus 2 days before the onset of hyperoxia exposure. Shown is a comparison of Ad.FGF1 administered at $5 \times 10^{9} \mathrm{VP}$ (solid triangles) or $10^{9}$ VP (solid circles) with Ad.V152 administered at $5 \times 10^{9} \mathrm{VP}$ (solid squares) or $10^{9} \mathrm{VP}$ (open squares). Each value is the percentage of surviving rats in each group of eight animals. Kaplan-Meier survival curves were compared by log rank test. $p$ Values less than 0.05 were considered statistically significant between animals treated with Ad.V152 or Ad.FGF1 at the same dose.

\section{Alveolar cell proliferation and apoptosis in hyperoxic rats}

Alveolar cell proliferation in nonhyperplastic areas of lungs from rats exposed to $95 \% \mathrm{O}_{2}$ for $48 \mathrm{hr}$ (Fig. 7A, panels a and b), as assessed by quantification of PCNA cell staining, was similar between the groups pretreated with Ad.V152 and Ad.FGF1 (2.67 \pm 0.29 and $2.65 \pm 0.74 \%$, respectively). However, in hyperplastic areas of lungs from Ad.FGF1-pretreated rats, proliferation was increased $(29.73 \pm 1.3 \%$ in hyperplastic areas versus $2.65 \pm 0.74 \%$ in normal areas).

The TUNEL technique was used to detect apoptosis 4 days after Ad.FGF1 or Ad.V152 administration followed by exposure to hyperoxia $\left(95 \% \mathrm{O}_{2}\right.$ for $\left.48 \mathrm{hr}\right)$. DNA strand breaks were detected mainly in bronchiolar cells and alveolar epithelial cells, either in normal or in hyperplastic areas. Some apoptotic cells appeared to be endothelial cells based on their location. Staining was more pronounced in hyperplastic areas than in normal areas in rats pretreated with Ad.FGF1 at any dose (Fig. 7A, panels $\mathrm{c}$ and d).

Evidence that caspase activation may be critical for many forms of apoptotic cell death prompted us to look for an increase in caspase activity in normoxic and hyperoxic rats $(95 \%$ $\mathrm{O}_{2}$ for $48 \mathrm{hr}$ ) 4 days after Ad.FGF1 administration. Figure 7B shows the changes in caspase 3 activity in lung tissue from six animals per group. No differences were found between rats pretreated with Ad.V152 or Ad.FGF1 (10 $0^{9}$ or $\left.5 \times 10^{9} \mathrm{VP}\right)$, and exposed to normoxia or to hyperoxia.

\section{DISCUSSION}

In this study, intratracheal administration of Ad.FGF1 resulted in expression of FGF-1 by bronchiolar and alveolar epithelial cells, as well as alveolar macrophages. The effect was dose dependent, with increasing doses of Ad.FGF1 producing patchy to diffuse lung transduction. In our model, a low dose of adenovirus induced strong expression of FGF-1 in BAL fluid but only minimal lung inflammation. Adenovirus-mediated lung FGF-1 overexpression increased the survival of rats exposed to hyperoxia. This effect was associated with a burst of alveolar type II cell proliferation and apoptosis.

Intratracheal Ad.FGF1 administration was efficient in ensuring local gene transfer with secretion of a functional protein by transduced cells. FGF-1 levels in BAL fluid recovered 4 days after Ad.FGF1 administration showed a dose-dependent increase. No increase in plasma FGF-1 was detectable with the Ad.FGF1 doses used in our study, suggesting that FGF-1 diffusion and expression in other organs were minimal. Histological examination revealed marked proliferation of bronchial and alveolar epithelial cells. This proliferation was confined to the terminal bronchoalveolar areas, indicating that adenovirus transduction and the resulting biological effects were heterogeneously distributed in the lungs after intratracheal adenovirus administration. The extent of lung involvement after Ad.FGF1 administration did not depend on the adenovirus injection technique but increased with the dose. Thus, after administration of $5 \times 10^{10}$ or $10^{11} \mathrm{VP}$, epithelial cell proliferation was visible in most of the lung. Because the VP-to-PFU ratio for Ad.FGF1 was $100,5 \times 10^{10}$ and $10^{11}$ VP corresponded, respectively, to $5 \times 10^{8}$ and $10^{9} \mathrm{PFU}$, which is the dose range used for most in vivo adenovirus transduction studies in rats. In our study, we used $10^{9}$ and $5 \times 10^{9} \mathrm{VP}$, that is, $10^{7}$ and $5 \times 10^{7} \mathrm{PFU}$, which are comparable to the doses defined as intermediate or low $\left(10^{9}-10^{11} \mathrm{VP}\right)$ in humans and well tolerated after local administration (Harvey et al., 2002). Although bronchial administration of adenovirus carrying the gene encoding the cystic fibrosis transmembrane regulator (Ad.CFTR) in humans was associated with local pneumonitis in one patient, adenovirus effect has not been tested at the onset of ALI in humans.

Over time, the histological changes seen on day 4 resolved gradually. Moreover, FGF-1 levels in BAL fluid peaked on day 4 and then decreased rapidly to values that were not significantly different from those in controls on days 10 and 17 after administration of $10^{9}$ or $5 \times 10^{9} \mathrm{VP}$ of Ad.FGF1. This finding may explain the gradual reversal of the lung epithelial proliferation induced by Ad.FGF1 administration. The short duration of FGF-1 expression is often a limitation to the use of adenoviruses as vectors for gene therapy in chronic diseases, but may be an advantage in our model of ALI. After exposure to hyperoxia, the rats died within 72 to $96 \mathrm{hr}$. Consequently, to improve survival, FGF-1 expression must reach a high level rapidly. However, prolonged expression is not needed: whereas alveolar type II cell proliferation during the early phase of ALI may restore injured epithelial cells, persistence of this effect with an inability to initiate spreading and differentiation to alveolar type I cells may produce a deleterious persistent hyperplastic response (Uhal et al., 1998). This persistent response may alter the extracellular matrix, thereby impairing recovery from ALI.

Hyperoxia causes extensive destruction of alveolar epithelial cells in monkeys (Kapanci et al., 1969) and humans (Gould et al., 1972). Although some studies found no significant damage to alveolar epithelial cells in rats exposed to hyperoxia (Crapo, 1986), ultrastructural studies showed disruption of the alveolar epithelium (Kistler et al., 1967; Harris et al., 1991). In 


\section{PCNA}
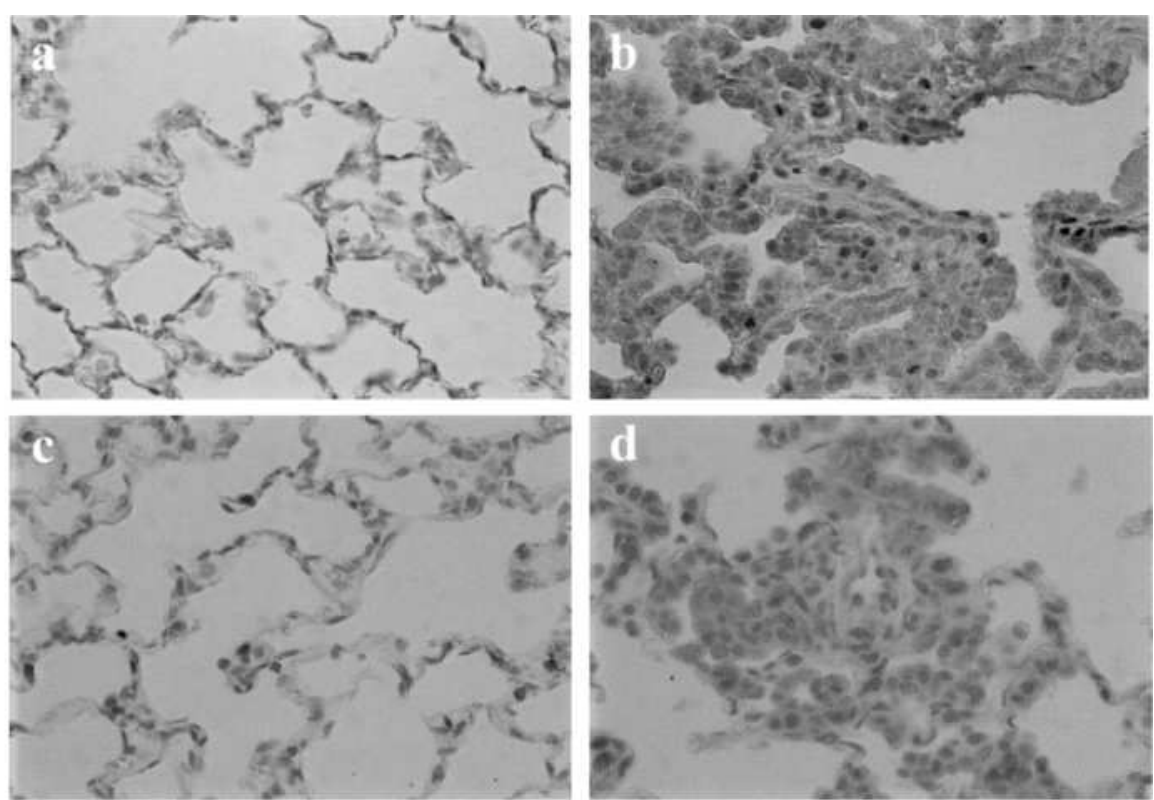

TUNEL
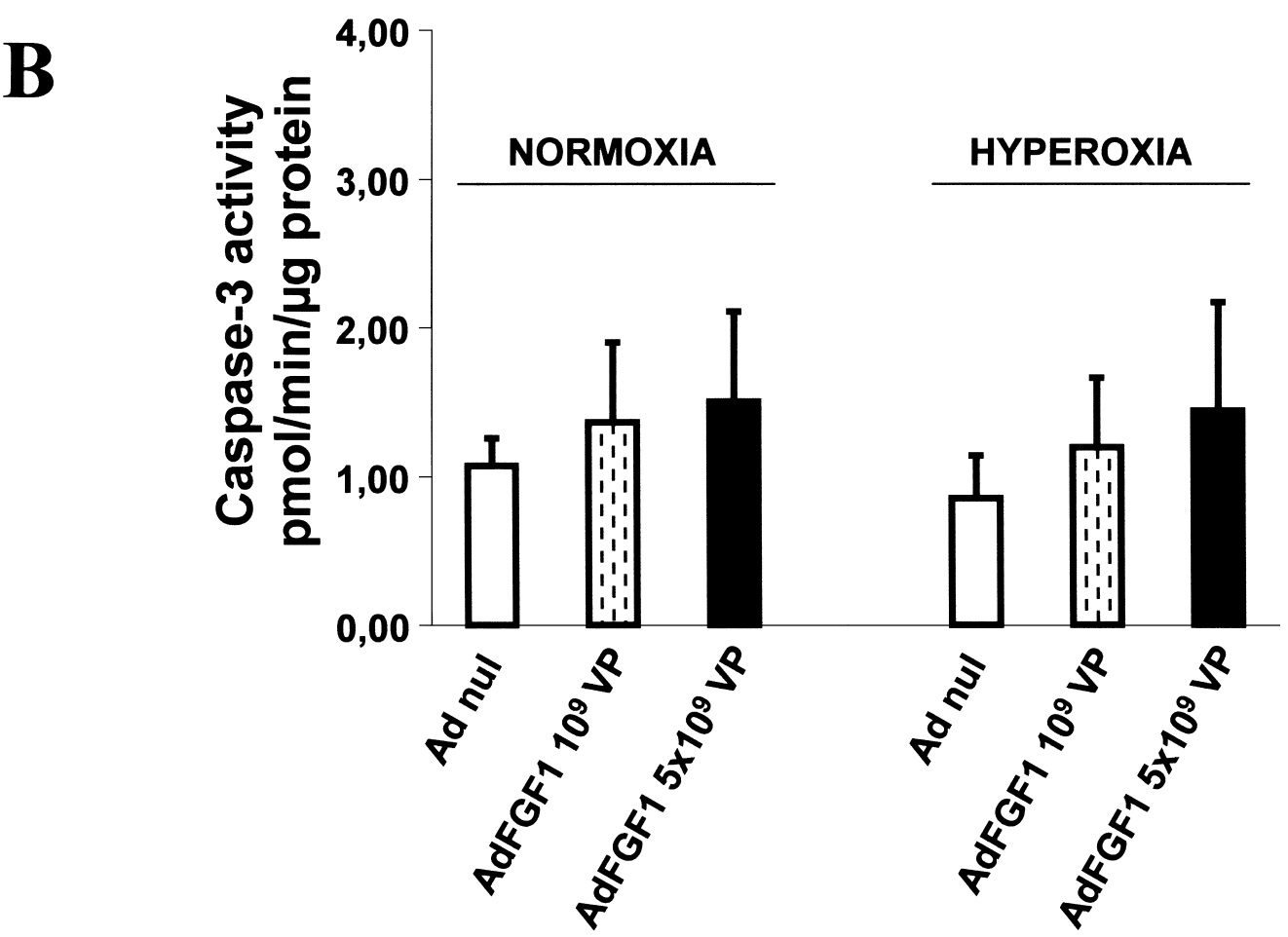

FIG. 7. Effect of Ad.FGF1 on cell proliferation and apoptosis. (A) PCNA (a and b) and TUNEL staining (c and d). Adenovirus (Ad.FGF1 or Ad.V152, $5 \times 10^{9} \mathrm{VP}$ ) was instilled intratracheally 2 days before a 48-hr period of exposure to $95 \% \mathrm{O}_{2}$. Immunohistochemistry for PCNA counterstained with hematoxylin shows positive staining (brown) for proliferating cells in the alveolar septa. (a) Ad.V152 $\left(5 \times 10^{9} \mathrm{VP}\right)$-treated rat lungs (same findings as in nonhyperplastic areas of Ad.FGF1-treated rat lungs); (b) Ad.FGF1 $\left(5 \times 10^{9} \mathrm{VP}\right)$-treated rat lungs (areas of hyperplasia). Original magnification: $(\mathrm{a}$ and b) $\times 25$. DNA fragmentation was evaluated by TUNEL assay as described in Materials and Methods. (c) Representative photomicrograph illustrating the levels of nuclear staining in Ad.V152-pretreated animals (identical to those in nonhyperplastic areas of lungs from Ad.FGF1-pretreated animals). (d) Representative photomicrograph illustrating the levels of nuclear staining in hyperplastic areas of Ad.FGF1-pretreated animals. Original magnification: (c and d) $\times 25$. (B) Comparison of caspase 3-like activity in the lungs 4 days after administration of Ad.V152 or Ad.FGF1 to rats exposed to normoxia or hyperoxia (95\% $\mathrm{O}_{2}$ for 48 hr). Caspase 3-like activity showed no differences between Ad.V152 and Ad.FGF1 ( $10^{9}$ or $\left.5 \times 10^{9} \mathrm{VP}\right)$ in normoxic or hyperoxic rats. Values represent means \pm SEM. $n=6$ in each experiment. 
rats briefly exposed to hyperoxia and then allowed to recover in room air, morphometric analysis showed a 2.5 -fold increase in the number of alveolar type II cells (Thet et al., 1986). Moreover, intratracheal administration of KGF (FGF-7), which induces proliferation of alveolar type II cells and cell hyperplasia, protected rats against hyperoxic lung injury (Panos et al., 1995; Guo et al., 1998). These findings are consistent with a reparative response of alveolar type II cells to alveolar epithelium injury and justify our choice of the rat hyperoxia model for investigating potential effects of FGF-1 on ALI. We showed that Ad.FGF1 instillation induced massive type II cell proliferation in normoxic and hyperoxic animals. PCNA staining established that lung epithelial proliferation was far more marked in Ad.FGF1-treated animals than in the controls. If, as suggested by Witschi (1990), healing of the alveolar epithelium requires a proliferative response of alveolar type II cells, then intratracheal Ad.FGF1 administration may afford protection by accelerating this response. Moreover, replicating alveolar cells may be more resistant to the deleterious effects of oxygen, as suggested by findings in neonatal rats (Frank et al., 1978; Canada et al., 1995). Surprisingly, intravenous administration of KGF to mice also protected against the effects of hyperoxia but did not induce alveolar proliferation, suggesting a paracrine effect of KGF on the endothelium (Barazzone et al., 1999). However, using a tetracycline-inducible lung-specific KGF transgenic system, Ray et al. showed that KGF inhibited lung epithelial cell death induced by hyperoxia but did not increase survival of the animals (Ray et al., 2002). Their ultrastructural studies showed preservation of the epithelial lining contrasting with apoptosis in the endothelium and accessory cells lining the capillaries (Ray et al., 2002). This disagreement between the effects of exogenous KGF and transgene-produced KGF may be ascribable to the difference in alveolar KGF doses $(1-5 \mathrm{mg} / \mathrm{kg}$ and $0.2-0.4 \mu \mathrm{g} / \mathrm{kg}$, respectively). The protection afforded by exogenous KGF may be due to effects of KGF unrelated to binding of FGF receptor 2-IIIb (FGFR2-IIIb), such as binding to other FGF receptors or secondary effects. This is additional evidence that proper repair requires a protective effect on both the epithelial and the endothelial side of the airspace. We used the less specific growth factor FGF-1, the angiogenic properties of which might conceivably result in cytoprotective effects on the endothelium. However, we were unable to study endothelial integrity on the histological sections because the burst of epithelial cell proliferation profoundly modified the alveolar septa. The improvement in survival after exposure to hyperoxia found in our study may be ascribable in part to FGF-1-induced type II cell proliferation and in part to protective effects of FGF-1 on endothelial cells. After adenoviral gene transfer, FGF-1 may act on type II cell proliferation through intracrine, autocrine, and paracrine mechanisms and on endothelial cells through paracrine mechanisms.

Additional modes of protection have been hypothesized, such as an increase in surfactant protein, stimulation of fibrinolytic activity, and decreased apoptosis (Barazzone et al., 1999). Work performed with a generated transgenic mouse strain characterized by conditional overexpression of a soluble FGF receptor showed that the FGF receptor pathway was critical for maintaining surfactant homeostasis and lung function after hyperoxia (Hokuto et al., 2004). KGF attenuates programmed cell death in some cell lines (Buckley et al., 1998; Wu et al., 1998), but we found no reduction in apoptosis after Ad.FGF1 admin- istration to hyperoxic rats. Apoptosis is an important mechanism for removing unwanted cells during injury repair, and extensive apoptosis has been documented during the resolution phase of ALI (Bardales et al., 1996). Persistent proliferation of alveolar type II cells may occur when the signals needed to end cell division are lacking and differentiation into type I cells cannot occur (Uhal et al., 1998). Our findings suggest that the hyperplasia-inducing stimulus caused by Ad.FGF1 administration was present only as long as FGF-1 was overexpressed. Nevertheless, Fehrenbach et al. (2000) emphasized the importance of alveolar type II cell apoptosis for the resolution of KGF-induced type II cell hyperplasia in rat lungs in vivo. They reported that KGF instillation induced terminal differentiation and apoptosis of hyperplastic type II cells in vivo, resulting in restoration of normal alveolar epithelium. Moreover, whether apoptosis plays a role in hyperoxia-induced lung injury remains debated. Work on A549 cells indicates that hyperoxia inhibits $\mathrm{H}_{2} \mathrm{O}_{2}$-induced apoptosis via an effect mediated by NF- $\kappa$ B (Franek et al., 2001). In our model, the slight increase in apoptosis may be related to resolution of the type II cell hyperplasia induced by FGF-1 rather than to a direct effect on oxygen toxicity.

\section{ACKNOWLEDGMENTS}

We thank E. Escudier and F. Bernaudin for processing the samples for transmission electron microscopy and for interpreting the results, and $\mathrm{D}$. Gruenert for the gift of the $1 \mathrm{HAEo}^{-}$ cell line. This work was supported in part by the nonprofit organization Association Française des Myopathies and by the Academy of Paris (Legs Poix).

\section{REFERENCES}

BARAZZONE, C., DONATI, Y.R., ROCHAT, A.F., VESIN, C., KAN, C.D., PACHE, J.C., and PIGUET, P.F. (1999). Keratinocyte growth factor protects alveolar epithelium and endothelium from oxygen-induced injury in mice. Am. J. Pathol. 154, 1479-1487.

BARDALES, R.H., XIE, S.S., SCHAEFER, R.F., and HSU, S.M. (1996). Apoptosis is a major pathway responsible for the resolution of type II pneumocytes in acute lung injury. Am. J. Pathol. 149, 845-852.

BLANCHE, F., CAMERON, B., BARBOT, A., FERRERO, L., GUILLEMIN, T., GUYOT, S., SOMARRIBA, S., and BISCH, D. (2000). An improved anion-exchange HPLC method for the detection and purification of adenoviral particles. Gene Ther. 7, $1055-1062$.

BRODY, S., METZGER, M., DANEL, C., ROZENFELD, M., and CRYSTAL, R. (1994). Acute response of non-human primates to airway delivery of an adenovirus vector containing the human CFTR cDNA. Hum. Gene Ther. 5, 821-836.

BUCKLEY, S., BARSKY, L., DRISCOLL, B., WEINBERG, K., ANDERSON, K.D., and WARBURTON, D. (1998). Apoptosis and DNA damage in type 2 alveolar epithelial cells cultured from hyperoxic rats. Am. J. Physiol. 274, L714-L720.

BURGESS, W.H., MEHLMAN, T., MARSHAK, D.R., FRASER, B.A., and MACIAG, T. (1986). Structural evidence that endothelial cell growth factor $\beta$ is the precursor of both endothelial cell growth factor $\alpha$ and acidic fibroblast growth factor. Proc. Natl. Acad. Sci. U.S.A. 83, 7216-7220.

CANADA, A.T., HERMAN, L.A., and YOUNG, S.L. (1995). An agerelated difference in hyperoxia lethality: Role of lung antioxidant defense mechanisms. Am. J. Physiol. 268, L539-L545. 
COZENS, A., YEZZI, M., YAMAYA, M., STEIGER, D., WAGNER, J., GARBER, S., CHIN, L., SIMON, E., and GRUENERT, D. (1992) A transformed human epithelial cell line that retains tight junctions post crisis. In Vitro Cell. Dev. Biol. 28A, 735-744.

CRAPO, J.D. (1986). Morphologic changes in pulmonary oxygen toxicity. Annu. Rev. Physiol. 48, 721-731.

CROUZET, J., NAUDIN, L., ORSINI, C., VIGNE, E., FERRERO, L., LE ROUX, A., BENOIT, P., LATTA, M., TORRENT, C., BRANELLEC, D., DENEFLE, P., MAYAUX, J.F., PERRICAUDET, M., and YEH, P. (1997). Recombinational construction in Escherichia coli of infectious adenoviral genomes. Proc. Natl. Acad. Sci. U.S.A. 94, $\underline{1414-1419 .}$.

DRISKELL, R.A., and ENGELHARDT, J.F. (2003) Current status of gene therapy for inherited lung disease. Annu. Rev. Physiol. 65, 585-612.

FACTOR, P., MENDEZ, M., MUTLU, G.M., and DUMASIUS, V. (2002) Acute lung injury does not impede adenoviral-mediated alveolar gene transfer. Am. J. Respir. Crit. Care Med. 165, 521-526.

FEHRENBACH, H., KASPER, M., KOSLOWSKI, R., PAN, T., SCHUH, D., MULLER, M., and MASON, R.J. (2000). Alveolar epithelial type II cell apoptosis in vivo during resolution of keratinocyte growth factor-induced hyperplasia in the rat. Histochem. Cell Biol. 114, 49-61.

FRANEK, W.R., HOROWITZ, S., STANSBERRY, L., KAZZAZ, J.A., KOO, H.C., LI, Y., ARITA, Y., DAVIS, J.M., MANTELL, A.S., SCOTT, W., and MANTELL, L.L. (2001). Hyperoxia inhibits oxidant-induced apoptosis in lung epithelial cells. J. Biol. Chem. 276, $\underline{569-575}$

FRANK, L., BUCHER, J.R., and ROBERTS, R.J. (1978). Oxygen toxicity in neonatal and adult animals of various species. J. Appl. Physiol. 45, 699-704.

GAVRIELI, Y., SHERMAN, Y., and BEN-SASSON, S.A. (1992). Identification of programmed cell death in situ via specific labeling of nuclear DNA fragmentation. J. Cell Biol. 119, 493-501.

GOULD, V.E., TOSCO, R., WHEELIS, R.F., GOULD, N.S., and KAPANCI, Y. (1972). Oxygen pneumonitis in man: Ultrastructural observations on the development of alveolar lesions. Lab. Invest. 26, 499-508.

GUO, J., YI, E.S., HAVILL, A.M., SAROSI, I., WHITCOMB, L., YIN, S., MIDDLETON, S.C., PIGUET, P., and ULICH, T.R. (1998). Intravenous keratinocyte growth factor protects against experimental pulmonary injury. Am. J. Physiol. 275, L800-L805.

HARRIS, J.B., CHANG, L.Y., and CRAPO, J.D. (1991). Rat lung alveolar type I epithelial cell injury and response to hyperoxia. Am. J. Respir. Cell Mol. Biol. 4, 115-125.

HARVEY, B.G., MARONI, J., O'DONOGHUE, K.A., CHU, K.W., MUSCAT, J.C., PIPPO, A.L., WRIGHT C.E., HOLLMANN, C., WISNIVESKY, J.P., KESSLER, P.D., RASMUSSEN, H.S., ROSENGART, T.K., and CRYSTAL, R.G. (2002). Safety of local delivery of low- and intermediate-dose adenovirus gene transfer vectors to individuals with a spectrum of comorbid conditions. Hum. Gene Ther. 13, 15-63.

HOKUTO, I., PERL, A.K.T., and WHITSETT, J.E. (2004) FGF signaling is required for pulmonary homeostasis following hyperoxia. Am. J. Physiol. 286, L580-L587.

JOUANNEAU, J., GAVRILOVIC, J., CARUELLE, D., JAYE, M., MOENS, G., CARUELLE, J.P., and THIERY, J.P. (1991). Secreted or nonsecreted forms of acidic fibroblast growth factor produced by transfected epithelial cells influence cell morphology, motility, and invasive potential. Proc. Natl. Acad. Sci. U.S.A. 88, 2893-2897.

KAPANCI, Y., WEIBEL, E.R., KAPLAN, H.P., and ROBINSON, F.R. (1969). Pathogenesis and reversibility of the pulmonary lesions of oxygen toxicity in monkeys. II. Ultrastructural and morphometric studies. Lab. Invest. 20, 101-118.

KIM, I., MOON, S., YU, K., KIM, U., and KOH, G.Y. (2001). A novel fibroblast growth factor receptor-5 preferentially expressed in the pancreas. Biochim. Biophys. Acta 1518, 152-156.

KISTLER, G.S., CALDWELL, P.R., and WEIBEL, E.R. (1967). De- velopment of fine structural damage to alveolar and capillary lining cells in oxygen-poisoned rat lungs. J. Cell Biol. 32, 605-628.

LESLIE, C.C., MCCORMICK-SHANNON, K., ROBINSON, P.C., and MASON, R.J. (1985). Stimulation of DNA synthesis in cultured rat alveolar type II cells. Exp. Lung Res. 8, 53-66.

LESLIE, C.C., MCCORMICK-SHANNON, K., and MASON, R.J. (1990). Heparin-binding growth factors stimulate DNA synthesis in rat alveolar type II cells. Am. J. Respir. Cell Mol. Biol. 2, 99-106.

LESLIE, C.C., MCCORMICK-SHANNON, K., SHANNON, J.M., GARRICK, B., DAMM, D., ABRAHAM, J.A., and MASON, R.J. (1997). Heparin-binding EGF-like growth factor is a mitogen for rat alveolar type II cells. Am. J. Respir. Cell Mol. Biol. 16, 379-387.

PANOS, R.J., RUBIN, J.S., CSAKY, K.G., AARONSON, S.A., and MASON, R.J. (1993). Keratinocyte growth factor and hepatocyte growth factor/scatter factor are heparin-binding growth factors for alveolar type II cells in fibroblast-conditioned medium. J. Clin. Invest. 92, 969-977. PANOS, R.J., BAK, P.M., SIMONET, W.S., RUBIN, J.S., and SMITH, L.J. (1995). Intratracheal instillation of keratinocyte growth factor decreases hyperoxia-induced mortality in rats. J. Clin. Invest. 96, 2026-2033.

RAY, P., DEVAUX, Y., STOLZ, D.B., YARLAGADA, M., WATKINS, S.C., YUNBIAO, L., CHEN, L., YANG, X.F., and RAY, A. (2002) Inducible expression of keratinocyte growth factor (GKGF) in mice inhibits lung epithelial cell death induced by hyperoxia. Proc. Natl. Acad. Sci. U.S.A. 100, 6098-6103.

SANNES, P.L., BURCH, K.K., and KHOSLA, J. (1992). Immunohistochemical localization of epidermal growth factor and acidic and basic fibroblast growth factors in postnatal developing and adult rat lungs. Am. J. Respir. Cell Mol. Biol. 7, 230-237.

SARIA, A., and LUNDBERG, J.M. (1983). Evans blue fluorescence: Quantitative and morphological evaluation of vascular permeability in animal tissues. J. Neurosci. Methods 8, 41-49.

SLEEMAN, M., FRASER, J., MCDONALD, M., YUAN, S., WHITE, D., GRANDISON, P., KUMBLE, K., WATSON, J.D., and MURISON, J.G. (2001). Identification of a new fibroblast growth factor receptor, FGFR5. Gene 271, 171-182.

STAUB, N.C. (1974). Pulmonary edema. Physiol. Rev. 54, 678-811. THET, L.A., PARRA, S.C., and SHELBURNE, J.D. (1986). Sequential changes in lung morphology during the repair of acute oxygeninduced lung injury in adult rats. Exp. Lung Res. 11, 209-228.

UHAL, B.D., JOSHI, I., HUGHES, W.F., RAMOS, C., PARDO, A., and SELMAN, M. (1998). Alveolar epithelial cell death adjacent to underlying myofibroblasts in advanced fibrotic human lung. Am. J. Physiol. 275, L1192-L1199.

ULICH, T.R., YI, E.S., LONGMUIR, K., YIN, S., BILTZ, R., MORRIS, C.F., HOUSLEY, R.M., and PIERCE, G.F. (1994). Keratinocyte growth factor is a growth factor for type II pneumocytes in vivo. J. Clin. Invest. 93, 1298-1306.

WITSCHI, H. (1990). Responses of the lung to toxic injury. Environ. Health Perspect. 85, 5-13.

WU, K.I., POLLACK, N., PANOS, R.J., SPORN, P.H., and KAMP, D.W. (1998). Keratinocyte growth factor promotes alveolar epithelial cell DNA repair after $\mathrm{H}_{2} \mathrm{O}_{2}$ exposure. Am. J. Physiol. 275, L780-L787.

Address reprint requests to: Dr. Bernard Maitre INSERM U492, Faculté de Médecine 8 Rue du Général Sarrail 94010 Creteil, France

E-mail: bernard.maitre@hmn.ap-hop-paris.fr

Received for publication November 29, 2003; accepted after revision June 29, 2004.

Published online: July 29, 2004. 